九州大学学術情報リポジトリ

Kyushu University Institutional Repository

\title{
Study on Measures for Promoting Woodenware Industry in Korea
}

Choi, Soo Im

Department of Forest Resources, Sunchon National University

Kang, Hag Mo

Department of Forest Environmental Science, Chonbuk National University

Sato, Noriko

Laboratory of Forest Policy, Division of Forest Environmental Sciences, Department of Agroenvironmental Sciences, Faculty of Agriculture, Kyushu University

https://doi.org/10.5109/27383

出版情報: 九州大学大学院農学研究院紀要. 58 (2)，pp.493-498，2013-09. Faculty of Agriculture， Kyushu University

バージョン :

権利関係 : 


\title{
Study on Measures for Promoting Woodenware Industry in Korea
}

\author{
Soo Im $\mathrm{CHOI}^{1}$, Hag Mo KANG ${ }^{2 *}$ and Noriko SATO \\ Laboratory of Forest Policy, Division of Forest Environmental Sciences, \\ Department of Agro-environmental Sciences, Faculty of Agriculture, \\ Kyushu University, Fukuoka 812-8581, Japan \\ (Received April 26, 2013 and accepted May 9, 2013)
}

\begin{abstract}
As of 2008, there are 70 or more woodenware related companies in Namwon, and they are accounted for $80 \%$ of the total production of woodenware in Korea. These companies installed Lacquer Art Museum, Wood Craft Complex, Lacquer Research Institute, and Lacquer Art Studio and planted lacquer tree in approximately 81 ha from 1997 to 2006 . However, the demand for the utensils for ancestral rites that increased from the mid 1980's has been decreasing gradually from the late 1990's along with the decrease of demand for dining table due to the sharp increase of imports from China and the change of table and ceremonial culture replacing traditional dining table. Under the circumstances, a survey was conducted with woodenware makers located in Namwon, the typical woodenware industry area of Korea, in order to find out the problems in management and seek for the ways to make improvements. As a result, most companies excluding few answered that the demand for the utensils for ancestral rites and the dining tables decreased sharply and expected it to decrease continuously. The purchase price of the raw timber is increasing each year, but the companies could not increase the price fearing that it would shrink consumer confidence. A number of companies were planning to decrease the production of or upgrade their products such as the utensils for ancestral rites and the dining tables in the future and also to increase the production of utensils for living that consume relatively less wood. Most companies decided to overcome difficult situations by diversifying the design and upgrading the quality considering that the woodenware is environment-friendly but experienced a number of difficulties such as the case where imports are circulated as domestic products, difficulty in securing skilled manpower, lack of financial resource for automated facilities, and decrease of demand.
\end{abstract}

Key words: woodenware industry, ceremonial culture, utensils, dining tables sawmills, woodland

\section{INTRODUCTION}

Korea's woodcraft made advancements with the Buddhism in the Goryeo Dynasty (918-1392), however, the "Worship Confucianism and Oppress Buddhism" policy in the Joseon Dynasty (1392-1910) is considered to have hindered the advancement of woodcraft technology. Later, the woodenware industry made a huge advancement after the techniques were introduced and people were trained under Japanese rule (1910-1945). However, the demand for woodenware decreased sharply after the 1950's due to the intensified regulation against lumbering after the war in the 1950's and the penetration of plastic and stainless steel utensils for living due to the industrialization in the 1970's. The woodenware industry which had been considered as the decaying industry, but the production and supply of the utensils for ancestral rites were revitalized due to the mass production enabled through the penetration of electricity and the construction of the Woodenware Production Complex (Namwon, Jeollabuk-do) (in the late 1970), and the improvement of the income level of the people increased their interest in traditional craft works. It is told that the woodenware industry of Namwon began to develop as the woodenware manufacturing techniques

\footnotetext{
Department of Forest Resources, Sunchon National University, Suncheon, 540-950, Korea

2 Department of Forest Environmental Science, Chonbuk National University, Chonju, 561-756, Korea

* Corresponding author (E-mail: kanghagmo@jbnu.ac.kr)
}

used to produce the rice bowl, utensils for living, and utensils for Buddhist rite for Buddhist priests of Silsangsa (temple, 828 A.D.) which was located in Sannae-myeon, Namwon during the Unified Silla Dynasty, were transferred to people in the district. There is a historical record stating that most woodenware used all around the kingdom was produced in Namwon during the Joseon Dyansty, and the reason the woodenware industry thrived in Namwon is that the area had access to abundant wood resources from Mt. Jiri in the proximity and technicians were trained under the Japanese rule. As of 2008, there were 70 or more woodenware related companies in Namwon and they accounted for $80 \%$ of the total woodenware production in Korea (Invention \& Patent, 2008; Ministry of Agriculture, 1997a; Ministry of Agriculture, 1997b), and Lacquer Art Museum, Wood Craft Complex, Lacquer Research Institute, and Lacquer Art Studio were constructed and lacquer trees were planted in approximately 81 ha areas from 1997 to 2006 in order to strengthen the basis for the indutry (Namwon City, 2011).

However, the demand for the utensils for ancestral rites that increased from the mid 1980's has been decreasing gradually since the late 1990's along with the decrease in demand for dining tables due to the sharp increase in imports from China and the change of table and ceremonial culture replacing traditional dining table (Korea Rural Economic Institute, 2004). Preceding studies on woodenware and woodcraft industries include the Characteristics of Wood Used in 
Woodcraft (Lee, 1991; Ministry of Agriculture, 1997a; Kim, 2002), Woodcraft Design and Product Development (Oh, 1992; Choi et al., 2005; Choi et al., 2007; Korea Forest Service, 2000; Korea Forest Service, 2002), Direction for Industrial Development (Ministry of Agriculture, 1997b; Korea Rural Economic Institute, 2004; Korea Research Institute for Local Administration, 2002; Ministry for Food, Agriculture, Forestry and Fisheries, 2009), however, it is difficult to find the empirical study on the management of woodenware makers.

Under the circumstances, a survey was conducted with woodenware makers located in Namwon, the typical woodenware industry area of Korea, in order to find out the problems in management and seek for the ways to make improvements.

\section{MATERIALS AND METHODS}

Considering the current status of woodenware related companies located in Namwon, the survey target, there are 93 companies and 402 professionals, and the sales per company was 100 200 million won (Namwon City, 2011), however, according to 2012 data, there are 42 woodenware makers, 8 woodenware lacquerers, 21 dining table makers, and 15 dining table lacquerers, total 86 companies including (Namwon City, 2012). However, the field survey showed that a number of companies are closed and the number of actually operating companies is estimated to be less than 86 , requiring a precise survey on the actual condition. The survey was conducted mostly with the companies that produce utensils for ancestral rites and for living as well as dining table using wood, however, mainly the ones located inside the Woodcraft Complex. Companies that refused to respond, where their responsible persons were away for a long time, and the ones closed temporarily were excluded from the survey and the number of companies that could be surveyed was 25. The survey was conducted through direct interviews for 3 months from the beginning of January to end of March, 2012 on general status including the operating period, the age of owner, and the average number of days worked in a month and the raw timber purchase volume, purchase price, goods produced, sales and circulation, management condition, and difficulties (Table 1).

\section{RESULTS AND DISCUSSIONS}

\section{Current Status of Woodcraft Industry in Korea}

It was difficult to collect data about overall woodenware industry in Korea as various statistics did not categorized the woodenware industry separately, and it is also difficult to find relevant data from the studies conducted until today. In the past, the Korea Foundation of Handicrafts Cooperatives prepared woodenware related statistical data, however, not presently, and it was only possible to confirm that 1,142 members joined 16 cooperatives around the country through Korea Foundation of Handicrafts Cooperatives where members included those who are engaged in woodenware, paper art, traditional paper, instrument, ceramics, and natural dye (Korea Federation of Handcrafts Cooperatives, 2012). According to the internal data of Namwon city, the Korean lacquer goods market was estimated at 26.2 billion won as of 2012 and the demand is expected to increase up to 240 billion won centering on table, lacquered table, utensils for ancestral rites, kitchen utensils, and automobile interior material as of 2017 (Namwon City, 2011).

\section{Case Study of Lumber Company}

\section{Current Status of Woodenware Company}

According to the current status of 25 companies surveyed, a variety of production formats were manifested such as utensils for ancestral rites + utensils for living (7), table (5), utensils for ancestral rites (4), utensils for ancestral rites + table (2), utensils for living (1), utensils for ancestral rites + rice bowl for Buddhist priests (1), utensils for ancestral rites + rice bowl for Buddhist priests + utensils for Buddhist rites (1), utensils for ancestral rites + utensils for living + funeral urn + other (1), rice bowl for Buddhist priests (1), candlestick (1), and other (1). Companies that only produced 1 type of goods were 5 table makers and 4 ancestral rite uten-

Table 1. Current Status of Woodcraft Industry in Namwon

\begin{tabular}{ccccccc}
\multicolumn{2}{c}{ Table 1. Current Status of Woodcraft Industry in Namwon } & & (Unit: Company) \\
\cline { 3 - 5 } Year & Total & Subtotal & Woodenware & Dining Table & Lacquerer & $\begin{array}{c}\text { Other } \\
\text { (Rice Bowl for Buddhist } \\
\text { Priest, Etc.) }\end{array}$ \\
\cline { 3 - 5 } 2005 & 139 & 94 & 65 & 29 & 32 & 13 \\
2006 & 123 & 83 & 50 & 33 & 28 & 12 \\
2007 & 129 & 83 & 59 & 24 & 34 & 12 \\
2008 & 122 & 83 & 59 & 24 & 27 & 12 \\
2009 & 115 & 78 & 56 & 22 & 26 & 11 \\
2010 & 103 & 71 & 50 & 21 & 22 & 10 \\
2011 & 93 & 69 & 48 & 21 & 14 & 10 \\
2012 & 86 & 63 & 42 & 21 & 8 & 15 \\
\hline
\end{tabular}

Source: 1. Namwon City. 2011 Internal data

2. Namwon City. 2012 Craft company 
sil makers, and the largest number of companies produced utensils for ancestral rite + utensils for living, and there were 7 of them. According to the general status of 25 companies, the age of the owner was 25 78 and the average was 58 , the average operating period was $6 \sim 50$ years and the average was 26 years. The average number of days worked in a month was 7 30 days and the average was 24 days, and the average number of employees was comprised of 2.1 family members and 4.5 employees and 6.6 employees per company. The monthly salary for men was 1.56 million won and that for women was 1.01 million won. Among 25 companies, there were 6 successors who are mostly young people in their 30s, and most of them succeeded to the family business of their grand father or father (Table 2).

\section{Current Status of Raw Timber Purchase, Production, and Sales}

25 woodenware companies are purchase raw timber to manufacture goods and they mostly purchase it through the timber dealers. In 2011, the total purchase volume of raw timber was $3,571 \mathrm{~m}^{3}$ and the cost was $822,240,000$ won, and the volume and cost per company were $5 \sim 810 \mathrm{~m}^{3}$ and 1,750,000 139,960,000 won and the averages were $143 \mathrm{~m}^{3}$ and $34,260,000$ won respectively. The raw timber purchased was comprised of alder (49\%), ash (32\%), and foreign trees (12\%) that were mostly alder and ash. The price of alder and ash per $\mathrm{m}^{3}$ was 160,000 won and 240,000 won, and that of foreign trees was 460,000 won. However, companies that produced utensils for ancestral rites and for living used domestic timber only, and companies that produced dining table mostly used foreign timber (Table 3).

The total woodenware sales of all 25 companies was 6.5 billion won, and utensils for ancestral rite (56\%) were sold most followed by dining table (27\%) and utensils for living (11\%) in respective order. The sales per company was 10 1,000 million won and the average was 260 million won, but the average sales of 22 companies excluding 3 companies that showed relatively high sales above 500 million won was 190 million (Table 4).

Manufactured products were comprised of wholesale products $(60 \%)$, retail products $(17 \%)$, and custom order (9\%), in respective order. However, by product category, wholesale products accounted for $73 \%$ as for table and custom order accounted for $50 \%$ as for the rice bowl for Buddhist priests. Table and the utensils for ancestral rites were mostly sold wholesale for manufacturers did not have a separate place exclusively for sales in a location frequented by people. Also, the reason the ratio of internet sales is low is that they do not have staff exclusively in charge of homepage management and

Table 2. General Status of Woodenware Manufacture (2011)

\begin{tabular}{|c|c|c|c|c|c|c|c|c|c|c|c|c|c|c|}
\hline \multirow{3}{*}{$\begin{array}{c}\text { Division } \\
(25 \\
\text { Companies })\end{array}$} & \multirow{3}{*}{$\begin{array}{l}\text { Age of } \\
\text { Owner } \\
\text { (Age) }\end{array}$} & \multirow{3}{*}{$\begin{array}{l}\text { Operating } \\
\text { Period } \\
\text { (Year) }\end{array}$} & \multirow{3}{*}{$\begin{array}{c}\text { Average } \\
\text { Number of } \\
\text { Days } \\
\text { Engaged in a } \\
\text { Month } \\
\text { (Days) }\end{array}$} & \multicolumn{7}{|c|}{ Employees (Person) } & \multicolumn{3}{|c|}{$\begin{array}{c}\text { Monthly Average } \\
\text { Salary } \\
(10,000 \text { Won })\end{array}$} & \multirow{3}{*}{$\begin{array}{c}\text { Successor } \\
\text { (Age) }\end{array}$} \\
\hline & & & & Total & & Family & & En & nploye & & \multirow{2}{*}{ Total } & \multirow{2}{*}{ Male } & \multirow{2}{*}{ Female } & \\
\hline & & & & 165 & Subtotal & 1 Male & Female & Subtotal & Male & Female & & & & \\
\hline Average & 58 & 26 & 24 & 6.6 & 2.1 & 2.0 & 0.6 & 4.5 & 2.4 & 2.1 & 129 & 156 & 101 & 36 \\
\hline
\end{tabular}

Table 3. Current Status of Raw Timber Purchase (2011)

(Unit: \%)

\begin{tabular}{|c|c|c|c|c|c|c|c|c|c|c|c|c|}
\hline \multirow[b]{2}{*}{$\begin{array}{c}\text { Division } \\
(25 \\
\text { Companies })\end{array}$} & \multicolumn{2}{|c|}{ Total } & \multicolumn{2}{|c|}{ Alder } & \multicolumn{2}{|c|}{ Ash } & \multicolumn{2}{|c|}{ Foreign } & \multicolumn{2}{|c|}{ Oak } & \multicolumn{2}{|c|}{ Other (3 Species) } \\
\hline & $\begin{array}{c}\text { Volume } \\
\left(\mathrm{m}^{3}\right)\end{array}$ & $\begin{array}{c}\text { Amount } \\
(10,000 \\
\text { Won) }\end{array}$ & $\begin{array}{l}\text { Volume } \\
\left(\mathrm{m}^{3}\right)\end{array}$ & $\begin{array}{l}\text { Amount } \\
(10,000 \\
\text { Won })\end{array}$ & $\begin{array}{l}\text { Volume } \\
\left(\mathrm{m}^{3}\right)\end{array}$ & $\begin{array}{c}\text { Amount } \\
(10,000 \\
\text { Won })\end{array}$ & $\begin{array}{l}\text { Volume } \\
\left(\mathrm{m}^{3}\right)\end{array}$ & $\begin{array}{c}\text { Amount } \\
(10,000 \\
\text { Won })\end{array}$ & $\begin{array}{l}\text { Volume } \\
\left(\mathrm{m}^{3}\right)\end{array}$ & $\begin{array}{c}\text { Amount } \\
(10,000 \\
\text { Won) }\end{array}$ & $\begin{array}{c}\text { Volume } \\
\left(\mathrm{m}^{3}\right)\end{array}$ & $\begin{array}{c}\text { Amount } \\
(10,000 \\
\text { Won })\end{array}$ \\
\hline Total & $\begin{array}{l}3,571 \\
(100)\end{array}$ & $\begin{array}{c}82,224 \\
(100)\end{array}$ & $\begin{array}{c}1,754 \\
(49)\end{array}$ & $\begin{array}{c}28,445 \\
(35)\end{array}$ & $\begin{array}{c}1,144 \\
(32)\end{array}$ & $\begin{array}{c}28,017 \\
(34)\end{array}$ & $\begin{array}{l}424 \\
(12)\end{array}$ & $\begin{array}{c}19,713 \\
(24)\end{array}$ & $\begin{array}{l}80 \\
(2)\end{array}$ & $\begin{array}{c}2.400 \\
(3)\end{array}$ & $\begin{array}{l}136 \\
(4)\end{array}$ & $\begin{array}{c}3,154 \\
(4)\end{array}$ \\
\hline Average & 143 & 3,426 & 125 & 2,032 & 76.3 & 1,868 & 85 & 3,943 & - & - & 28 & 646 \\
\hline
\end{tabular}

Note: Figures inside ( ) refers to distribution ratio (\%).

Table 4. Sales Status of Woodenware (2011)

(Unit: Million Won, \%)

\begin{tabular}{|c|c|c|c|c|c|c|c|c|c|}
\hline $\begin{array}{c}\text { Division } \\
(25 \\
\text { Companies })\end{array}$ & Total & $\begin{array}{c}\text { Utensils for } \\
\text { Ancestral } \\
\text { Rite }\end{array}$ & $\begin{array}{l}\text { Dining } \\
\text { Table }\end{array}$ & $\begin{array}{c}\text { Utensils } \\
\text { for } \\
\text { Living }\end{array}$ & $\begin{array}{c}\text { Rice Bowl } \\
\text { for Buddhist } \\
\text { Priest }\end{array}$ & $\begin{array}{c}\text { Funeral } \\
\text { Urn }\end{array}$ & $\begin{array}{c}\text { Utensils for } \\
\text { Buddhist } \\
\text { Rite }\end{array}$ & Candlestick & Other \\
\hline Total & $\begin{array}{c}65.4 \\
(100)\end{array}$ & $\begin{array}{l}36.7 \\
(56)\end{array}$ & $\begin{array}{l}17.6 \\
(27)\end{array}$ & $\begin{array}{c}6.9 \\
(11)\end{array}$ & $\begin{array}{l}2.0 \\
(3)\end{array}$ & $\begin{array}{l}0.6 \\
(1)\end{array}$ & $\begin{array}{l}0.4 \\
(1)\end{array}$ & 0.1 & $\begin{array}{l}1.1 \\
(2)\end{array}$ \\
\hline Average & 2.6 & - & - & - & - & - & - & - & - \\
\hline
\end{tabular}

Note: Figures inside ( ) refers to distribution ratio (\%). 
Table 5. Sales Status of Woodenware (2011)

\begin{tabular}{|c|c|c|c|c|c|c|c|}
\hline Division & Total & Wholesale & Retail & $\begin{array}{l}\text { Custom } \\
\text { Order }\end{array}$ & $\begin{array}{c}\text { Large } \\
\text { Shopping } \\
\text { Mall }\end{array}$ & Internet & $\begin{array}{c}\text { TV } \\
\text { Home } \\
\text { Shopping }\end{array}$ \\
\hline Total & $\begin{array}{c}65.4 \\
(100)\end{array}$ & $\begin{array}{l}39.3 \\
(60)\end{array}$ & $\begin{array}{l}11.0 \\
(17)\end{array}$ & $\begin{array}{l}6.2 \\
(9)\end{array}$ & $\begin{array}{l}3.6 \\
(6)\end{array}$ & $\begin{array}{l}2.7 \\
(4)\end{array}$ & $\begin{array}{l}2.6 \\
(4)\end{array}$ \\
\hline $\begin{array}{l}\text { Utensils for Ancestral Rites } \\
\text { (16 Companies) }\end{array}$ & $\begin{array}{l}36.7 \\
(100)\end{array}$ & $\begin{array}{l}22.5 \\
(61)\end{array}$ & $\begin{array}{c}5.0 \\
(14)\end{array}$ & $\begin{array}{l}1.8 \\
(5)\end{array}$ & $\begin{array}{c}3.6 \\
(10)\end{array}$ & $\begin{array}{l}1.2 \\
(3)\end{array}$ & $\begin{array}{l}2.6 \\
(7)\end{array}$ \\
\hline $\begin{array}{l}\text { Utensils for Living } \\
\text { (4 Companies) }\end{array}$ & $\begin{array}{c}6.9 \\
(100)\end{array}$ & $\begin{array}{c}3.9 \\
(57)\end{array}$ & $\begin{array}{c}1.3 \\
(19)\end{array}$ & $\begin{array}{c}1.2 \\
(17)\end{array}$ & - & $\begin{array}{l}0.5 \\
(7)\end{array}$ & - \\
\hline $\begin{array}{l}\text { Rice Bowl for Buddhist Priest } \\
\text { (3 Companies) }\end{array}$ & $\begin{array}{c}2.0 \\
(100)\end{array}$ & - & $\begin{array}{l}1.0 \\
(50)\end{array}$ & $\begin{array}{c}1.0 \\
(50)\end{array}$ & - & - & - \\
\hline $\begin{array}{l}\text { Dining Table } \\
\text { (7 Companies) }\end{array}$ & $\begin{array}{c}17.6 \\
(100)\end{array}$ & $\begin{array}{l}12.9 \\
(73)\end{array}$ & $\begin{array}{l}3.7 \\
(21)\end{array}$ & - & - & - & - \\
\hline $\begin{array}{l}\text { Utensils for Buddhist Rites } \\
\text { (1 Companies) }\end{array}$ & 0.4 & - & - & 0.4 & - & - & - \\
\hline $\begin{array}{l}\text { Funeral Urn } \\
\text { (1 Companies) }\end{array}$ & 0.6 & - & - & 0.6 & - & - & - \\
\hline $\begin{array}{c}\text { Fan / Ginseng Box } \\
\text { (1 Companies })\end{array}$ & 0.5 & - & - & 0.5 & - & - & - \\
\hline $\begin{array}{c}\text { Candlestick Processing } \\
\text { (1 Companies) }\end{array}$ & 0.1 & - & - & 0.1 & - & - & - \\
\hline $\begin{array}{c}\text { Other } \\
\text { (1 Companies) }\end{array}$ & 0.1 & - & - & 0.6 & - & - & - \\
\hline
\end{tabular}

Note: Figures inside ( ) refers to distribution ratio (\%).

operation, and in many cases of the internet sales the products are damaged during delivery and are returned according to respondents. Furthermore, some customers who purchased the products on the internet return the products for the discrepancy between their preferences and the actual product in terms of color and size after receiving the product, which causes losses such as logistics cost (Table 5). On the other hand, logging residues were produced in the process of manufacturing the woodenware, and 11 of 25 companies sold them in the form of saw dust mainly to stock farmers. They were sold at 900,000 10,000,000 won and the average per company was 3,200,000 won, and the companies that did not sold logging residues mostly used them by themselves as the fuel for heating.

\section{Management Condition and Difficulties}

First, most companies excluding few answered that the demand for the utensils for ancestral rites and the dining tables decreased sharply and expected it to decrease continuously due to the Western table culture replacing traditional dining tables and the changes in the ceremonial culture. On the other hand, most companies surveyed purchased raw timber from the areas outside nearby areas, and according to respondents, the reason is that the raw wood they need is almost exhausted in the nearby areas and it is difficult to secure a fixed amount of materials. In other words, the purchase price of the raw timber is increasing each year, but the companies could not increase the price fearing that it would shrink consumer confidence and they expected that it will be more difficult to secure raw timber in the future. For this, a number of companies were planning to decrease the production of or upgrade their products such as the utensils for ancestral rites and the dining tables in the future and also to increase the production of utensils for living that consume relatively less wood. Most companies producing utensils for living answered that the demand has increased than before, but they have limitations for mass production as most manufacturing processes are manually done.

However, most companies decided to overcome difficult situations by diversifying the design and upgrading the quality considering that the woodenware is environment-friendly but experienced a number of difficulties such as the case where imports are circulated as domestic products, difficulty in securing skilled manpower, lack of financial resource for automated facilities, and decrease of demand that 5 companies considered closure, 4 companies considered downsizing, and 15 companies considered maintaining current position.

\section{CONCLUSION}

1. In Namwon city, the target of the survey, there were 86 woodenware related companies including 42 woodenware makers, 8 woodenware lacquerers, 21 table makers, and 15 table lacquerers according to the preliminary survey. However, the field survey showed that a number of companies are closed. 
2. Namwon city estimated that the demand for Korean lacquered goods will increase up to 240 billion won centering on table, lacquered table, utensils for ancestral rites, kitchen utensils, and automobile interior material as of 2017.

3. The 25 companies surveyed manufactured a variety of products excluding 5 companies that only produced utensils for ancestral rites and 4 companies, dining tables. In terms of the types of goods the most company manufactured 7 companies produced utensils for ancestral rite and for living.

4. The average age of owners of 25 companies was 58 , the average operating period was 26 years, and the average number of days engaged in a month was 24 , the average number of professionals was 6.6, the monthly average salary for men was 1.56 million won and that for women was 1.01 million won, and there were 6 successors who are mostly young people in their 30s.

5 . The purchase volume and cost for raw timber per company were $143 \mathrm{~m}^{3}$ and 34,260,000 won, and the alder (49\%) was the most purchased timber followed by ash (32\%) and foreign trees (12\%), in respective order. However, companies that produced utensils for ancestral rites and for living used domestic timber only and companies that produced dining table mostly used foreign timber.

6. The total woodenware sales of all 25 companies was comprised of utensils for ancestral rite (56\%), dining table (27\%), and utensils for living (11\%), in respective order, and the average sales of 22 companies excluding 3 companies that showed relatively high sales above 500 million won was 190 million.

7. Most products manufactured were sold wholesale (60\%), retail (17\%), and customer order (9\%), however, in terms of product type, the wholesale accounted for $73 \%$ of the sales of the dining table and the customer order, $50 \%$ of the sales of the rice bowl for Buddhist priest.

8. Companies had many difficulties such as the case where imports were circulated as well as domestic products, difficulty in securing skilled manpower, lack of financial resource for automated facilities, and decrease of demand, but decided to overcome difficult situations by diversifying the design and upgrading the quality.

Therefore, the following measures shall be implemented in order to develop the woodenware industry of Namwon city into the locally based specialized industry.

1. The demand for the utensils for ancestral rites and the table is not expected to increase sharply regardless of new demands due to the nuclearization and the simplification of ancestral rites. It is necessary to develop and upgrade a variety of products that are used in real life instead of sticking to existing products such as the utensils for ancestral rites and the table.

2. Regarding raw materials required for lacquer varnish, Namwon, one of the areas surveyed, is relying on imports that cost much less than domestic products. It is necessary to develop a system that supplies raw materials for lacquer inside the country in the future in order stabilize the woodenware industry.

3. Currently, the woodenware makers of Namwon are operating based on independent production and independent sales system, however, the joint production and sales system appears to be desirable for cost reduction.

4. Companies were most worried about the supply of the raw timber which becomes the raw material for woodenware. It seemed that it is necessary to review the measure of making the best use of the public forest of the local government in order to secure raw materials stably.

5. There had been some studies about the tree species that can be used for woodenware production, the increase of costs including transportation cost due to geographical disadvantage or small amount will give negative influence on the management that it is necessary to consider the measure of finding species that can be easily supplied from nearby regions and supporting expenses such as for drying and resin removal expenses based on local government budget to a certain degree.

6. Lastly, Namwon city has constructed and is operating a variety of facilities including Lacquer Art Museum and Lacquer Research Institute in order to develop stable basis for the woodenware industry, however, the city needs to provide greater interest and financial support in the area of cultivating professional people required by the woodenware industry.

\section{ACKNOWLEDGEMENTS}

This research was carried out under a collaborative research project, "Policy development for improvement of wood self-sufficiency ratio and the socio-economic effects on mountainous areas in East Asia" with financial support from JSPS ((B) 25292090).

\section{REFERENCES}

Gu hwan Oh. 1992 Study on Modern Woodcraft Works of Korea. Dong-A University Master's Thesis

Invention \& Patent. 2008 Namwon Woodware

Korea Research Institute for Local Administration. 2002 The Policies of Local Government to Develop Regional Strategic Industries

Ki Choi et al. 2005 A Study on the Development of Design for Travel Souvenir Connected with a Local on the Wood-Craft Industry of Inje-county in Gangwon-province. Journal of Korean Society of Design Science 60(18): 303-314

Ki Choi et al. 2007. A Study on Development and Operation of a Wood Craft Edutainment Program for Fostering the Major Local Industry. Journal of the Korean Society of Design Culture 13(3): 179-191.

Korea Forest Service. 2000 Design Development and Marketing Strategy for Modernizing Traditional Woodcrafts in Korea

Korea Forest Service. 2002 Study on Woodcraft Design (Cultural) Product Development

Korea Federation Handcrafts Cooperatives. 2012 www.kohand. or.kr

Korea Rural Economic Institute. 2004 A Study on the Development of Local-Based Industry

Minister of Agriculture and Forestry. 1997a Development of 
Specialization Technologies to Uplift

Minister of Agriculture and Forestry. 1997b Development of Wooden Art FOR Rural Industry

Ministry for Food, Agriculture, Forestry and Fisheries, 2009 Study on the Direction for Rural Economy Revitalization through the Promotion of Agriculture and Fishery Industry

Namwon City. 2011 Internal Data
Namwon City. 2012 Craft Companies

Sa-Ick Kim. 2002 Development of Wooden Artifacts with Laminated Lumber. Korea Furniture Society Journal, 13(1) $10-17$

Young MI Lee. 1991 Study on the Characteristics and Utilization Method for Woodcraft Materials. Sookmyung Women's University Master's Thesis 